\title{
EFFECT OF DIFFERENT RATES OF WOOD ASH ON EXCHANGEABLE ALUMINUM, GROWTH, NODULATION, NITROGEN ACCUMULATION AND GRAIN YIELD OF SOYBEAN (GLYCINE MAX (L.) MERRILL) IN AN ACID ULTISOL
}

D. O. NOTTIDGE AND C. C. NOTTIDGE

(Received 21 May 2012; Revision Accepted 29 August 2012)

\section{ABSTRACT}

Response of soybean grown on acidic soil to wood ash applied at $0,2,4,6$, and $8 \mathrm{t} \mathrm{ha}^{-1}$ was studied in two field experiments in 2003 and 2004 at Umudike in the rainforest zone of Southeast Nigeria. Treatments were fitted in a randomized complete block design (RCBD) replicated three times. Effect of treatments on some soil fertility and productivity parameters were evaluated. The wood ash contains $64.30 \mathrm{~g} \mathrm{~kg}^{-1} \mathrm{Ca}, 12.20 \mathrm{~g} \mathrm{~kg}^{-1} \mathrm{Mg}, 9.03 \mathrm{~g} \mathrm{~kg}^{-1} \mathrm{~K}, 8.75$ $\mathrm{g} \mathrm{kg}^{-1} \mathrm{P}$ and $4.84 \mathrm{~g} \mathrm{~kg}^{-1} \mathrm{~N}$, and had a pH of 11.07. Soil pH increased significantly from 4.80 to 6.40 , while levels of exchangeable $\mathrm{Al}^{3+}$ correspondingly decreased from initial values of $2.50 \mathrm{cmol} \mathrm{kg}{ }^{-1}$ to $0.21 \mathrm{cmol} \mathrm{kg}^{-1}$ when $4 \mathrm{t} \mathrm{ha}^{-1}$ of wood ash was applied. Estimation of linear and quadratic curves respectively for soil $\mathrm{pH}$ and exchangeable $\mathrm{Al}^{3+}$ indicated values of $r^{2}=0.973^{\star *}$ for soil $\mathrm{pH}$ and $\mathrm{R}^{2}=0.944^{\star *}$ for exchangeable $\mathrm{Al}^{3+}$. Significant increases $(\mathrm{P}<0.01)$ in soil $\mathrm{Ca}, \mathrm{P}, \mathrm{K}$, status relate to patterns of growth, nodulation, nitrogen accumulation and grain yield of soybean. The application of $4 \mathrm{tha}^{-1}$ wood ash gave grain yield of $2028.34 \mathrm{~kg} \mathrm{ha}^{-1}$ compared with $0 \mathrm{t} \mathrm{ha}^{-1}$, and this was significantly $(P<0.01)$ higher than values obtained from either 2,6 or $8 \mathrm{tha}^{-1}$. Thus, the effect of the application of $4 \mathrm{t} \mathrm{ha}^{-1}$ was more outstanding and is recommended if high grain yields are to be obtained.

KEY WORDS: Soil Acidity, Wood Ash, Growth, Nodulation, Grain Yields, Southeast, Nigeria.

\section{INTRODUCTION}

Soybean (Glycine max (L.) Merrill) is an important grain legume crop and plays key role in many agricultural systems by providing high protein grain as well as maintaining and improving soil fertility (Nottidge, 1991; Russell, et al, 1985). The campaign for the production and utilization of soybean commenced because other sources of protein namely, meat, eggs, fish, and milk were very expensive and out of reach of the majority of people. The production of soybean in the tropical rainforest of southeast Nigeria is limited by soil acidity (Nottidge, 1991). The detrimental effects of high soil acidity are traceable largely to exchangeable aluminum levels. Hydrolysis of $\mathrm{Al}^{3+}$ generates $\mathrm{H}^{+}$and buffers the increase in soil solution $\mathrm{pH}$ (Havlin, et al, 2006). Soil pH will not increase until sufficient lime is added to decrease the soluble $\mathrm{Al}^{3+}$. An acid regime may prevent the development of an effective legumerhizobium symbiosis since the rhizobia might be unable to multiply in the host rhizosphere (Graham and Donawa, 1981), resulting in poor yields of the crop. Application of ash to acid soils normally increases yield (Nottidge, et al, 2007) and can be all that is necessary for profitable soybean production.

Although the problems of low $\mathrm{pH}$ and associated toxic levels of exchangeable $\mathrm{Al}$, deficiency of $\mathrm{Ca}$ and $\mathrm{Mg}$ can be ameliorated using calcitic limestone (Nottidge, 1991; Igbokwe et al, 1981; Anandan et al, 1985), their high cost, unavailability, imbalanced nutrition and other problems associated with their use have necessitated the use of organic sources of lime and fertilizer, wood ash for controlling acidity and building up nutrient supply (Nottidge, 2005).

Wood ash contains various amounts of plant nutrients: $\mathrm{Ca}, \mathrm{Mg}, \mathrm{N}, \mathrm{P}, \mathrm{K}, \mathrm{Na}, \mathrm{Fe}, \mathrm{Mn}, \mathrm{Cu}$, and $\mathrm{Zn}$; their chemical composition varies widely depending on the nature of plant burnt, the plant part and intensity of burning (Lallgee, 2000; Spaargaren, 1990; Nottidge, 2005). The beneficial effect of wood ash in improving soil chemical properties, ear leaf nutrient composition, growth and grain yields of maize (Zea mays L.) had been established (Owolabi, et al, 2003; Nottidge et al, 2006; Nottidge et al, 2007). Liming improves nutrient availability and affects the soil microbial population and activities (Sartian, 1985). Crops may also differ in tolerance to soil acidity and response to application of ash; therefore, the results obtained with one crop may not be wholly applicable to other crops. The objective of the study was therefore, to find a suitable wood ash rate for growth, nodulation, nitrogen accumulation and yield of soybean in acid Ultisol of the rainforest zone of Nigeria.

\section{MATERIALS AND METHODS}

Two experiments, one in the last week of July 2003 and another in the first week of August, 2004, were conducted at the National Root Crops Research Institute, (NRCRI) Umudike. Umudike is located on latitude $05^{\circ} 29^{\prime} \mathrm{N}$ and longitude $07^{\circ} 33^{\prime} \mathrm{E}$ and at an elevation of $122 \mathrm{~m}$ above sea level. Mean annual rainfall of $2171 \mathrm{~mm}$ is distributed over nine months in a bimodal rainfall pattern. The soil at the experimental site was 
sandy loam and had the following characteristics: $\mathrm{pH}$ 4.80; exchangeable Aluminum $2.50 \mathrm{cmol} \mathrm{kg}^{-1}$; Nitrogen $0.05 \%$; Organic carbon $1.18 \%$; available Phosphorus $12.00 \mathrm{mg} \mathrm{kg}^{-1}$; and exchangeable Calcium, Magnesium and Potassium were $1.50,0.60$ and $0.15 \mathrm{cmol} \mathrm{kg}^{-1}$ respectively.

The experimental sites were slashed, discploughed and harrowed by tractor. Plot size of $3 \mathrm{~m} \times 3 \mathrm{~m}$ were marked out and the different levels of wood ash dust collected from bakery industries in Umuahia sieved to remove undesirable materials were incorporated at about $15-20 \mathrm{~cm}$ depth using hoe into the various plots at $0,2,4,6$ and $8 \mathrm{tha}^{-1}$. The experimental design was a randomized complete block design (RCBD) replicated three times. Soybean variety TGX 1445-2E was planted at $60 \mathrm{~cm} \times 5 \mathrm{~cm}$ in all plots. The sampling area was 2.5 $\mathrm{m} \times 2.0 \mathrm{~m}$.

\section{Soil and ash analysis}

Soil samples $(0-15 \mathrm{~cm}$ depth) were collected from each experimental unit at harvest of soybean, airdried and sieved through 2-mm mesh. Soil $\mathrm{pH}$ was determined by electrometric method using a soil water ratio of 1: 2.5. Organic carbon was determined by Walkely-Black titration method. Soil total nitrogen was determined using the microkjeldahl method. Cations were leached with $1 \mathrm{~N} \mathrm{NH}_{4} \mathrm{OAc}$ at $\mathrm{pH}$ 7.0. Potassium and sodium were determined on flame photometer while calcium and magnesium were by EDTA titration. Exchange acidity was determined as described by Yuan (1959). Soil cation exchange capacity (CEC) was measured by summation of the amounts of exchangeable cations and exchange acidity. Phosphorus was determined using Bray-1 method (Bray and Kurtz, 1945). Mechanical analysis was done by the hydrometer method after dispersing soil with sodium hexametaphosphate. Wood ash was similarly analyzed.

\section{Agronomic parameters}

Nodulation, shoot dry weight and shoot nitrogen accumulation were used to evaluate the symbiotic effectiveness of soybean grown at different rates of wood ash. For this purpose fifteen plants selected at random from each treatment at physiological stage of flowering were carefully dug out and the soil from the roots carefully washed away with water. Nodules were carefully removed, counted and oven-dried at $70^{\circ} \mathrm{C}$ to a constant weight. The shoot biomass was similarly dried for computation of total dry matter. Shoots were subsequently weighed and ground in a mill for determination of $\mathrm{N}$ content by the microkjeldahl method (Yoshida et al, 1976). The total $\mathrm{N}$ in plant was computed according to Dhygga and Waines (1989).

\section{Statistical analysis}

Data collected were subjected to analysis of variance (ANOVA). The two-year data were pooled after a non-significant test for heterogeneity of variances. The effect of wood ash on some soil chemical properties, growth, nodulation, nitrogen accumulation and grain yield of soybean was analyzed using curvilinear regression. Regression analysis was performed on treatment means averaged over replications (Gomez and Gomez, 1984). Regression equations were statistically compared by using the parameter estimates (Ratkowsky, 1983).

\section{RESULTS}

Results from initial soil analysis and field trials confirmed high levels of exchangeable aluminum of 2.50 $\mathrm{cmol} \mathrm{kg}^{-1}$ and low Ca status of the Ultisol at Umudike. The soil is strongly acid with a pH of 4.80 . The N, P and $\mathrm{K}$ status are low. These soil properties are responsible for the response in growth, nodulation, nitrogen accumulation and grain yield of soybean obtained in the field to varying levels of wood ash. The chemical compositions of the wood ash are shown in Table 1.

Table 1: Chemical composition of wood ash

\begin{tabular}{ll}
\hline Nitrogen $\left(\mathrm{g} \mathrm{kg}^{-1}\right)$ & 4.84 \\
Phosphorus $\left(\mathrm{g} \mathrm{kg}^{-1}\right)$ & 8.75 \\
Potassium $\left(\mathrm{g} \mathrm{kg}^{-1}\right)$ & 9.03 \\
Calcium $\left(\mathrm{g} \mathrm{kg}^{-1}\right)$ & 64.30 \\
Magnesium $\left(\mathrm{g} \mathrm{kg}^{-1}\right)$ & 12.20 \\
$\mathrm{pH}$ & 11.10 \\
\hline
\end{tabular}

Effect of wood ash on soil pH, exchangeable aluminum and calcium status

The estimated response curves showing the effect of different levels of wood ash on soil pH, exchangeable $\mathrm{Al}^{3+}$ and $\mathrm{Ca}^{2+}$ are presented in Figures 1, 2 and 3. Soil $\mathrm{pH}$ and exchangeable $\mathrm{Ca}^{2+}$ and $\mathrm{Mg}^{2+}$
(Figure 4) increased linearly while levels of exchangeable $\mathrm{Al}^{3+}$ correspondingly decreased with rates of wood ash applied from 4 to $8 \mathrm{t} \mathrm{ha}^{-1}$. The prevailing strongly acidic condition in the no-ash treatment plots $(0$ $\mathrm{t} \mathrm{ha}^{-1}$ ) were significantly reduced to slightly acid condition of $\mathrm{pH} 6.40$ with $4 \mathrm{tha}^{-1}$ application. 


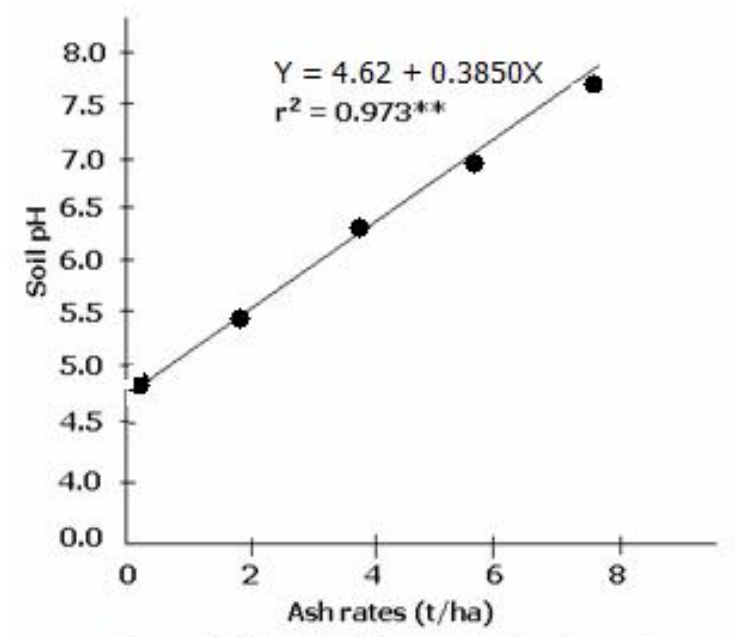

Figure 1: Effect of different levels of wood ash on soil pH

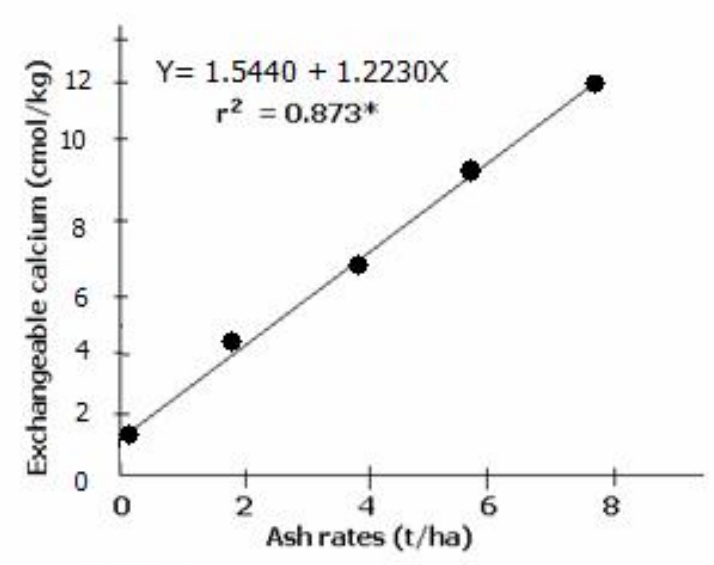

Figure 3: Effect of different levels of wood ash on soil exchangeable calcium
The application of $6 \mathrm{t} \mathrm{ha}^{-1}$ raised the soil $\mathrm{pH}$ to 7.10 , while further increase with $8 \mathrm{tha}^{-1}$ wood ash raised $\mathrm{pH}$ to 7.50. These results were consistent throughout the study period. The magnitude of coefficient of determination for some of the estimated response curves were highly significant $(P=0.01)$.

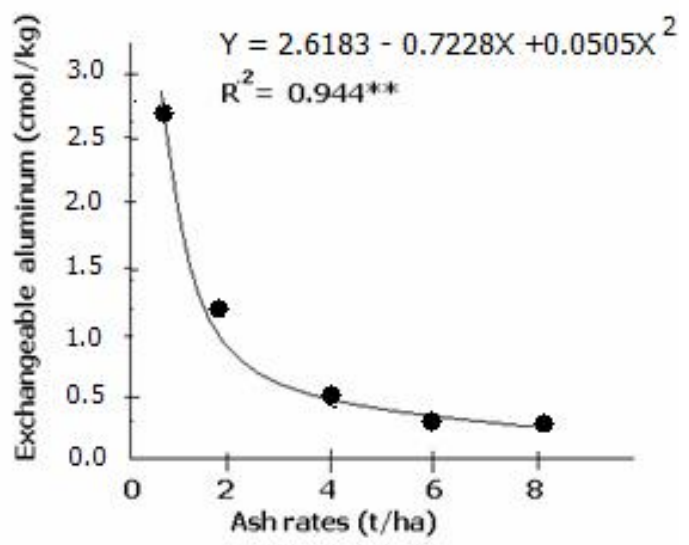

Figure 2: Effect of different levels of wood ash on soil exchangeable aluminum

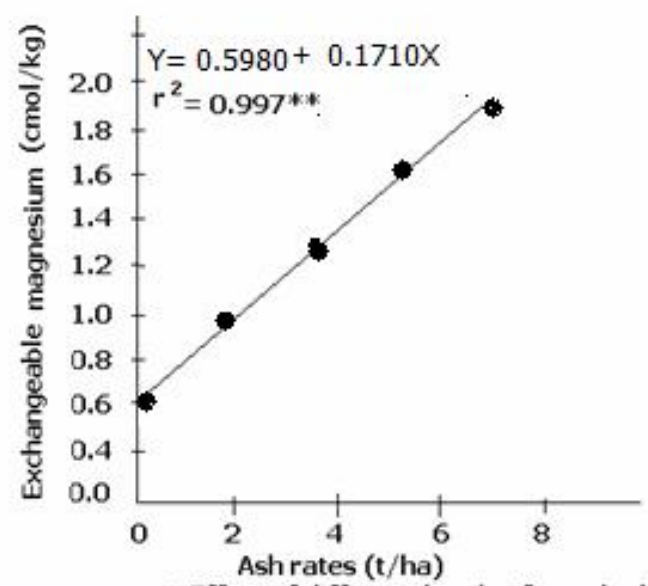

Figure 4: Effect of different levels of woodash on soil exchangeable magnesium

Effect of wood ash on soil phosphorus and potassium status

The estimated response curves depicting the effects of different levels of wood ash on soil available $P$ and exchangeable $\mathrm{K}$ status are shown in Figures 5 and 6 . Although increases in the values of these elements were significant up to $4 \mathrm{tha}^{-1}$ application, but at 6 and $8 \mathrm{t}$ $\mathrm{ha}^{-1}$ applications, slight increases in the values of soil $\mathrm{P}$ and $\mathrm{K}$ were dictated but these were not significantly $(\mathrm{P}<$ 0.05) different for soil exchangeable $K$ up to $8 \mathrm{tha}^{-1}$ except for $\mathrm{P}$. The wood ash contains more potassium than phosphorus (Table 1). 


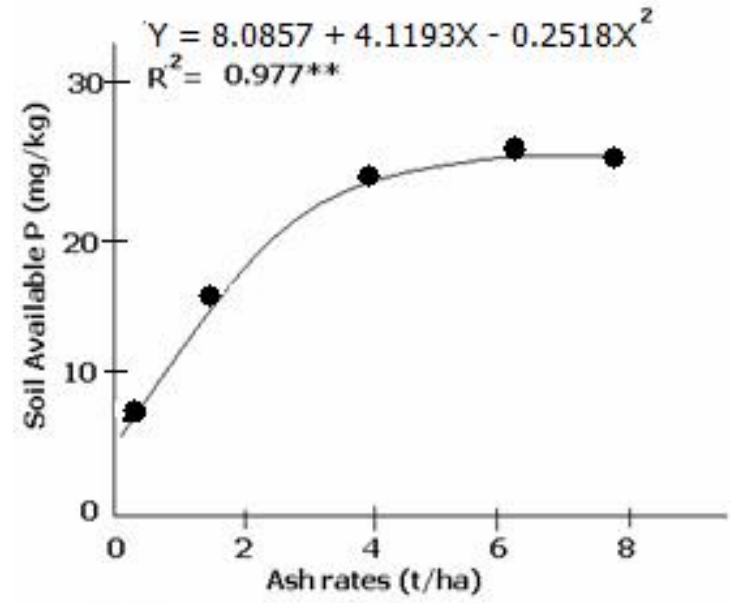

Figure 5: Effect of different levels of wood ash on soil available phosphorus
Effect on growth, nodulation, nitrogen accumulation and grain yields of soybean

Regression of shoot dry weight, nodule dry weight, shoot nitrogen accumulation and grain yields on wood ash rates indicated that optimum shoot, nodule weight and shoot nitrogen accumulation at both $4 \mathrm{t}$ and $6 \mathrm{t} \mathrm{ha}^{-1}$ wood ash ranked similarly while $8 \mathrm{t} \mathrm{ha}^{-1}$ application significantly $(P=0.05)$ caused reduction in

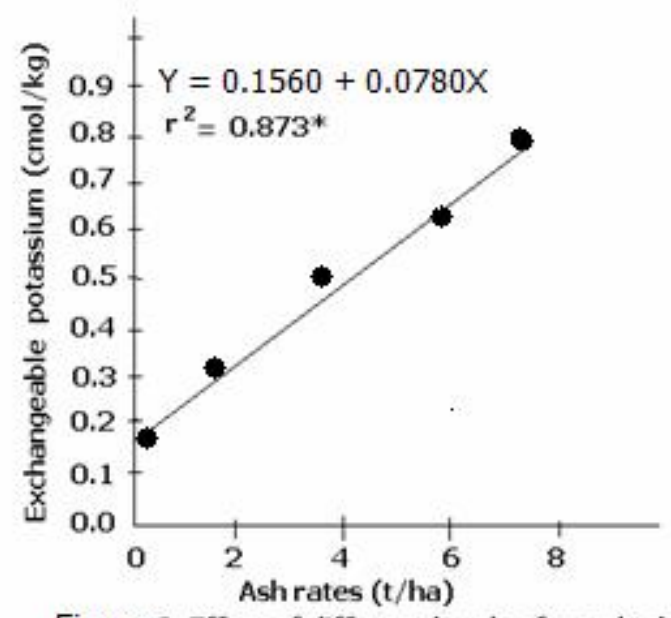

Figure 6: Effect of different levels of wood ash on soil exchangeable potassium the values of these parameters (Figures 7,8 and 9). An optimum grain yield of soybean was achieved with $4 \mathrm{t}$ $\mathrm{ha}^{-1}$ wood ash. The $8 \mathrm{t} \mathrm{ha}^{-1}$ application significantly decreased grain yields of the crop (Figure 10). Both the observed and predicted response on the bases of the curves estimation in Nottidge et al, (2006) on optimum wood ash rates compared favorably showing the validity of the results obtained in the present study.

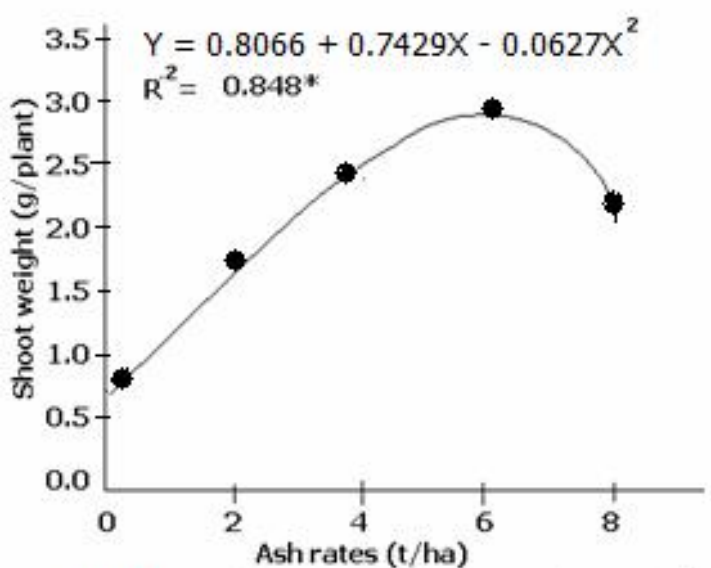

Figure 7: Effect of different levels of wood ash on shoot dry weight of soybean

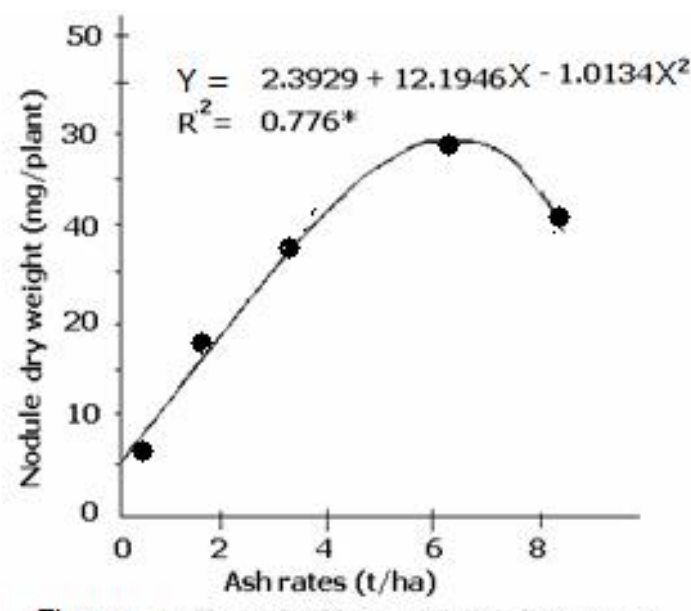

Figure 8: Effect of different levels of wood ash on nodulation 


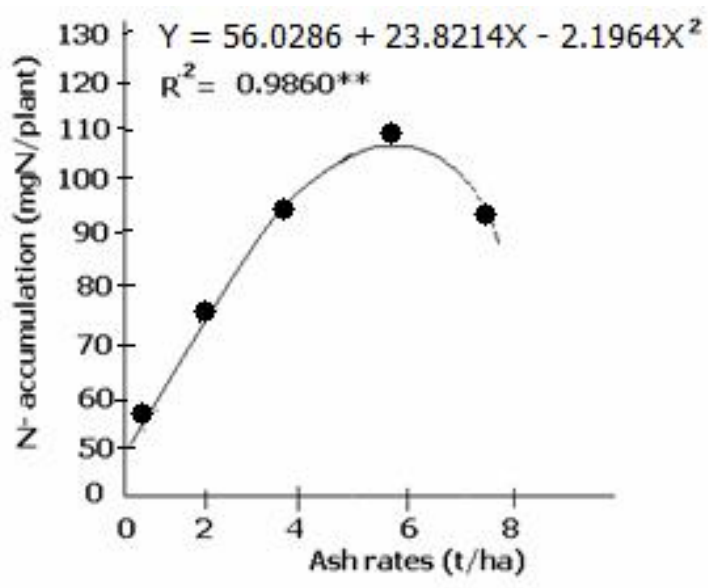

Figure 9: Effect of different levels of wood ash on shoot nitrogen accumulation

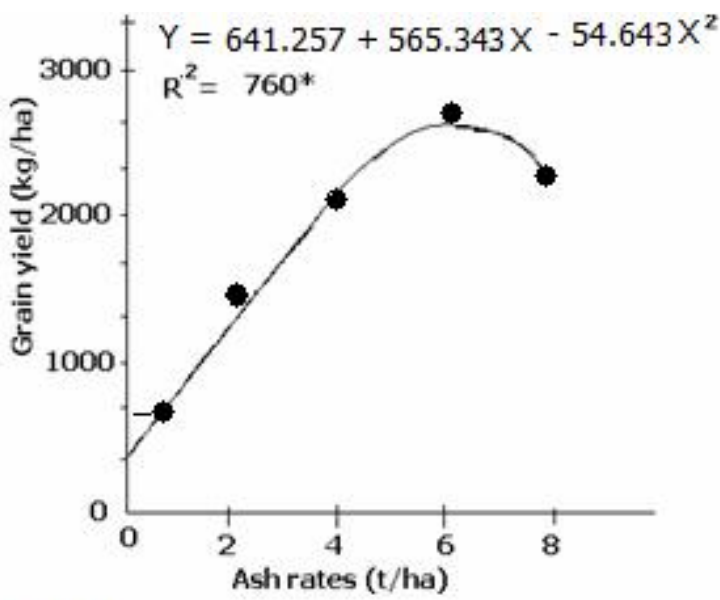

Figure 10: Effect of different levels of wood ash on grain yield of soybean

\section{DISCUSSION}

Results from soil analysis confirmed high levels of soil exchangeable $\mathrm{Al}^{3+}$ and very low calcium status of

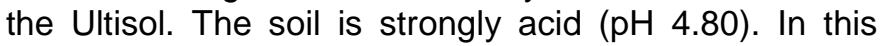
experiment, significant differences in all the parameters studied were obtained when wood ash was applied at $4 \mathrm{t}$ $\mathrm{ha}^{-1}$. The increase in soil pH from 4.80 to 6.40 (Figure 1 ) and reduction in the levels of exchangeable $\mathrm{Al}^{3+}$ from 2.61 to $0.10 \mathrm{cmol} \mathrm{kg}^{-1}$ (Figure 2) to crop tolerant level is commonly recognized (Nottidge, et al, 2006). The indirect effects of treatments on nutrient availability of Ca from 1.52 to $10.20 \mathrm{cmol} \mathrm{kg}^{-1}$; $\mathrm{Mg}$ from 0.61 to 1.95 $\mathrm{cmol} \mathrm{kg}^{-1}$; available $\mathrm{P}$ from 8.50 to $25.00 \mathrm{mg} \mathrm{kg}^{-1}$ and exchangeable $\mathrm{K}$ from 0.12 to $0.70 \mathrm{cmol} \mathrm{kg}^{-1}$ (Figures 3, 4,5 and 6 ) and on the toxicity of Al were established (Nottidge, 2005).

In all the soil fertility indices studied, both the predicted and observed response of soil properties on the bases of the buffer curves compared favorably showing the validity of results. The results obtained on the effect of treatments on soil properties are in agreement with that on wood ash on maize (Nottidge et al, 2006). The increase in soil pH could be ascribed to the calcium ions (Figure 3 ) released into the soil solution during microbial decarboxylation of the ash (Natscher and Schwetnman, 1991). Exchangeable Ca correlated positively and significantly with soil pH $(r=0.98)$.

Closely related to soil $\mathrm{pH}$ was the decrease in exchangeable $\mathrm{Al}^{3+}$ (Figure 2) to crop tolerant level. The toxicity of Al was associated with stubby roots only when the soil exchangeable Al was $1.76 \mathrm{cmol} \mathrm{kg}^{-1}$. The decrease in exchangeable $\mathrm{Al}^{3+}$ could be ascribed to the precipitation of $\mathrm{Al}(\mathrm{OH})_{3}$ which occurred at the increased soil pH. Marion et al, (1976) had shown that at $\mathrm{pH}$ above 6.00 aluminum exists in the soil as insoluble $\mathrm{Al}(\mathrm{OH})_{3}$. The Al toxicity of roots according to Abruna et al, (1975) was a result of excess $\mathrm{Al}$ in the roots. The Al toxicity of roots expressed as stubbiness is possibly due to its interference on the phosphorylation of sugars, as reported by Clarkson, (1967).

Soil reaction plays an important role on growth, nodulation and nitrogen accumulation patterns of some legumes especially in relation to $\mathrm{pH}$, nutrient availability and uptake (Russell et al, 1985; Barnard and Folscher, 1988). Application of wood ash at $4 \mathrm{t} \mathrm{ha}^{-1}(\mathrm{pH}$ 6.40) enhanced greater accumulation of shoot $\mathrm{N}$ when compared with the no-ash treatment (Figure 9). The N accumulated by the plants could be an important input in the management of $\mathrm{N}$ content of the soil for succeeding crops (Nottidge and Ojeniyi, 2007). A positive relationship between greater top growth and $\mathrm{N}$ accumulation (Figures 7 and 9) was established $(r=$ 0.95). From Figures 8 and 9, a relationship between nodule dry weight and $\mathrm{N}$ accumulation was also established $(r=0.92)$.

The relatively poor growth, nodulation and $\mathrm{N}$ accumulation in the control can largely be attributed to problems of $\mathrm{Ca}$ and $\mathrm{P}$ deficiency. The increase in grain yields of soybean following increase in soil $\mathrm{pH}$ and availability of nutrients especially phosphate with addition of wood ash at $4 \mathrm{t} \mathrm{ha}^{-1}$ (Figure 10) as observed in this study is in agreement with those of Nottidge et al, (2007) on maize and Anandan et al, (1985) on peanut. Increase in the grain yields of soybean resulting from the application of $4 \mathrm{tha}^{-1}$ could be due to the suppression of toxic levels of exchangeable $\mathrm{Al}^{3+}$. Such decrease in exchangeable $\mathrm{Al}^{3+}$ enabled better nodulation of roots resulting in higher yields of soybean.

A great deal may be inferred regarding the physiological condition of the experimental units treated with $8 \mathrm{t} \mathrm{ha}^{-1}$ wood ash from its $\mathrm{pH}$ value, much more than from any other single analytical datum. According to Havlin et al, (2006), liming soils to $\mathrm{pH} 7.0$ can reduce $\mathrm{P}$ availability because of the precipitation of $\mathrm{Ca}$ or $\mathrm{Mg}$ phosphates. A liming program should be planned so that the $\mathrm{pH}$ can be kept between 6.0 and 6.50 (Brady and Weil, 1999). This is very important since $P$ reduction could impair nodulation and nitrogen fixation of soybean (Brady and Weil, 1999).

\section{CONCLUSION}

Wood ash is a plant residue and contains $\mathrm{N}, \mathrm{P}$, $\mathrm{K}, \mathrm{Ca}$ and $\mathrm{Mg}$ in varying amounts absorbed by the plant during normal growth. Wood ash applied at $4 \mathrm{tha}^{-1}$ 
significantly increased soil $\mathrm{pH}$, availability of nutrients and grain yield of soybean grown in acid soil compared with $0 \mathrm{t} \mathrm{ha}^{-1}$. Increasing the application of wood ash from $4-6$ t ha $^{-1}$ showed a corresponding reduction in grain yields of soybean and when it was further increased from 6 - $8 \mathrm{t} \mathrm{ha}^{-1}$, growth, nodulation and grain yields were significantly $(P<0.05)$ reduced. The values obtained from $0 \mathrm{t} \mathrm{ha}^{-1}$ and those of $2 \mathrm{t} \mathrm{ha}^{-1}$ were diminishing. Consequently, the application of $4 \mathrm{t} \mathrm{ha}^{-1}$ tended to be cost effective and showed more economic advantage to the soybean farmer when planted on an acid Ultisol in Nigeria.

\section{REFERENCES}

Abruna, F., Pearson, R. W and Perez, E., 1975. Lime response of corn and Ultisols of Puerio Rico In: Soil management in tropical America. (Edition, Bomemisya E, and Alvaredo),Raleigh, N.C., North Carolina State. $261-282$.

Anandan, K. M. S., Chandrasekaran, S and Arunachlam, G., 1985. Effect of Lime on Exchangeable Aluminum, Nodulation and Yield of Peanut (Arachis hypogaea L.) in an Acid Oxisol. Tropical Agriculture (Trinidad) (62): 39 - 45.

Barnard, R. O and Folscher, W. J., 1988. Growth of Legumes at Different Levels of Liming. Tropical Agriculture (Trinidad) (57): $333-341$.

Brady, N. C and Weil, R. R., 1999. The Nature and Properties of Soils. $12^{\text {th }}$ edition. Prentice, Hall, New Jersey.

Bray, R. H and Kurtz, L. T., 1945. Determination of Total Organic and Available forms of Phosphorus in Soils. Soil Science (59): $39-45$.

Clarkson, D. T., 1967. Excess of Aluminum, Plant and Soil. 27, $344-347$.

Dhugga, K. S and Waines, J. D., 1989. Analysis of $\mathrm{N}$ Accumulation and Use in Bread and Durum Wheat. Crop Science (29): 1232 - 1239.

Gomez, K. A and Gomez, A. A., 1984. Statistical procedures for agricultural research. $2^{\text {nd }}$ edition. John Wiley and Sons, New York, NY.

Graham, R. A and Donawa, A. L., 1981. Effect of Soil $\mathrm{pH}$ and Inoculum Rate on Shoot weight, Nitrogenase Activity and Competitive Nodulation of Groundnut (Arachis hypogaea L.), Tropical Agriculture (Trinidad). (58): 337 - 340.

Havlin, J. L., Beaton, J. D., Tisdale, S. L and Nelson, W. L., 2006. Soil Fertility and Fertilizers - An Introduction to Nutrient Management, $7^{\text {th }}$ edition. $52-53$.

Igbokwe, M. C., Njoku, B. O and Odurukwe, S. O., 1981. Liming Effects on the Response of Maize to Phosphate Fertilizer on an Ultisol in Eastern Nigeria. Nigerian Journal of Soil Science. (11): $120-130$.
Lallgee, B., 2000. Fertilizer Materials from Sugar Industry By-products. African Soils (31): 215 232.

Marion, G. M., Hendricks, D. M., Dult, G. R and Fuller, W. H., 1976. Aluminum and Silica Solubility in Seals. Soil Science. (121): $76-85$.

Natschner, L and Schwetmann, U., 1991. Proton Buffering in Organic horizons of Acid Forest Soils. Geoderma (48): 93 - 106.

Nottidge, D. O., 1991. Effect of Different Levels of Lime on Growth, Nodulation, Nitrogen Accumulation and Yield of Soybean (Glycine max. (L.) Merrill) in an Ultisol. PGD Thesis, Enugu State University of Science and Technology.

Nottidge, D. O., 2005. An Investigation into the Use of Leguminous Crop Residues and Wood Ash for Improving Soil Conditions and Productivity of Maize (Zea mays L.) in Southeast Nigeria. Ph.D. Dissertation, Michael Okpara University of Agriculture. Umudike.

Nottidge, D. O., Ojeniyi, S. O and Asawalam, D. O., 2006. Effect of Different Levels of Wood Ash on Soil Chemical Properties in an Acid Ultisol of Southeast Nigeria. Nigerian Journal of Soil Science. (16): $109-114$.

Nottidge, D. O and Ojeniyi, S. O., 2007. Effect of Different Residues of Leguminous Food Crops on Nutrient Composition and Grain Yield of Maize (Zea mays L.) in an Acid Ultisol of Southeast Nigeria. Proceedings of the $41^{\text {st }}$ Annual Conference of the Agricultural Society of Nigeria (ASN). October 22 - 26.Samaru.

Nottidge, D. O., Ojeniyi, S. O and Asawalam, D. O., 2007. Effect of Different Levels of Wood Ash on Nutrient Contents of Maize (Zea mays L.) and Grain Yield in an Acid Ultisol of Southeast Nigeria. Nigerian Journal of Soil Science. (17): 98 - 103.

Owolabi, O., Adeleye, A., Oladejo, B. T and Ojeniyi, S. O., 2003. Effect of Wood Ash on Soil Fertility and Crop Yield in Southwest Nigeria. Nigerian Journal of Soil Science (13): $55-60$.

Ratkowsky, D. H., 1983. Nonlinear Regression Modeling. Marcel Dekker, New York, NY. Russell, S.Y.,

Evans, D. O and Saidy, N. A., 1985. Tropical Legumes for N Production: Growth and N Content in Relation to Soil $\mathrm{pH}$. Tropical Agriculture (Trinidad) 62: $20-24$.

Sartian, J. B., 1985. Effect of Acidity and N-source on the Growth and Thatch Accumulation Tifgreen Bermudagrass and on Soil Nutrient Retention. Agronomy Journal (77): 33 - 36. 
Spaargaren, O., 1990. Africa Land-acid Soils Network.

In FBSRAM Newsletter. 16:4.

Yoshida, S., Forno, D. A., Cock, J. H and Gomez, K., 1976. Analysis for Total Nitrogen (Organic nitrogen) in Plant Tissues. In: Laboratory Manual for Physiological Studies of Rice. $3^{\text {rd }}$ edition, Manila, The International Rice Research Institute.

Yuan, T. L., 1959. Determination of Exchangeable Hydrogen in Soil by a Titration Method. Soil Science (88): $164-167$. 